\title{
PERSEPSI KONSUMEN TERHADAP KEPUTUSAN PEMBELIAN BERAS MERAH PRODUKSI KWT "KASIH IBU" DI KECAMATAN GULUK - GULUK KABUPATEN SUMENEP
} Ir. Purwati Ratna $\mathbf{W}^{1)^{*} \text {, Henny Diana Wati }}{ }^{2)}$, Nurul Latifah ${ }^{3)}$

1)*, 2) Dosen Program Studi Agribisnis, Universitas Wiraraja

3) Mahasiswa Program Studi Agribisnis, Universitas Wiraraja e-mail : purwatiratna1@gmail.com ${ }^{1 *}$, hennydianawati97@gmail.com ${ }^{2)}$, nurullatifah160898@gmail.com ${ }^{3)}$

\begin{abstract}
ABSTRAK
Berbicara tentang persepsi konsumen tentunya akan berbeda dan persepsi tersebut akan berkaitan langsung dengan keputusan konsumen untuk membeli suatu produk. Dengan adanya KWT "Kasih Ibu" sebagai satu-satunya usaha beras merah yang ada di Desa Bragung Kecamatan Guluk-Guluk, akan menjadi pertimbangan bagi masyarakat untuk mengonsumsi beras merah tersebut. Selain itu, akan banyak persepsi dari masyarakat atau konsumen terkait dengan beras merah yang menjadi makanan pokok atau keunggulannya dibandingkan dengan makanan pokok lainnya.Penelitian ini dilaksanakan di Kabupaten Sumenep dengan pertimbangan Kabupaten Sumenep merupakan salah satu daerah yang memiliki keanekaragaman pangan seperti beras merah. Lokasi penelitian pada Kelompok Wanita Tani (KWT) "Kasih Ibu" Desa Bragung Kecamatan Guluk-Guluk Kabupaten Sumenep. Lokasi diambil dengan alasan daerah tersebut merupakan sentra beras merah di Kabupaten Sumenep Tujuan penelitian ini adalah menganalisis persepsi konsumen terhadap beras merah dan menganalisis sejauh manakah hubungan antara persepsi dengan keputusan pembelian konsumen beras merah. Sehingga nantinya akan diketahui hubungan dari keseluruhan variabel persepsi konsumen dengan keputusan membeli oleh konsumen beras merah.

Analysis of variance merupakan metode untuk menguji hubungan antara satu variabel dependen (skala metrik) dengan satu atau lebih variabel independen (skala nonmetrik dengan level lebih dari dua). Hubungan antara satu variabel dependen metric dan dua variabel independen nominal sering disebut dengan Two Ways Anova.ANOVA digunakan untuk mengetahui pengaruh utama (main effect) dan pengaruh interaksi (interaction effect) dari variabel independen nominal (sering disebut faktor) terhadap variabel dependen metrik. Sedangkan target luaran dalam penelitian ini yaitu bisa terpublikasi dalam jurnal cemara yang akan diterbitkan tahun 2020.

Kemajuan hasil penelitian menunjukkan adanya hubungan yang dignifikan antara rasa, harga, ketersediaan produk dan manfaat kesehatan terhadap keputusan pembelian beras merah di KWT "Kasih Ibu” tersebut. Sedangkan status luaran yang ditargetkan tercapai.
\end{abstract}

Kata Kunci :persepsi konsumen, keputusan pembelian, hubungan

\section{PENDAHULUAN}

Padi beras merah adalah salah satu jenis padi yang dibudidayakan oleh petani. Akan tetapi, di Indonesia beras merah ini kurang mendapatkan perhatian dibandingkan dengan padi yang berasnya berwarna putih, padahal beras merah mengandung gizi tinggi (Purwaningsih, 2009). Beras merah merupakan komoditas pangan yang unggul dalam produktivitas dan ketahanan terhadap penyakit, kemudahan dalam pemeliharaan, biaya produksi yang dibutuhkan, umur panen yang juga hampir sama dengan komoditas 
padi lainnya (Indrasari, 2007). Selain itu, beras merah ini merupakan bahan pangan yang beredar di pasar dan digunakan sebagai bahan baku atau produk dari makanan sehat yang berbentuk tepung beras merah, dengan demikian adanya beras merah tersebut dapat menjadi solusi dalam menangani masalah kekurangan pangan dan gizi. Pada sisi konsumen, rasa nasi yang diolah dari beras merah lebih baik dibandingkan dengan rasa nasi yang biasa dikonsumsi (Suardi, 2005).

Saat ini masyarakat mulai berubah dalam hal gaya hidup dan pola makan yang sehat, karena banyak makanan yang dominan lemak tinggi dan berpotensi mengakibatkan penyakit yang berbahaya. Oleh karen itu, sangat diperlukan sebuah produk yang membantu meminimalisir penyakit berbahaya tersebut (shaharudin, 2010). Beras merah adalah jenis padi yang yang sering kita kenal karena kaya akan manfaat, biasanya beras merah ini sering digunakan perempuan untuk mendukung proses diet, akan tetapi manfaat dari beras merah tidak hanya itu. Mengingat kandungan lemak pada beras merah yang sangat kecil

Kabupaten Sumenep merupakan daerah di Jawa Timur yang memiliki keanekaragaman tanaman pangan, salah satunya padi beras merah yang hingga saat ini masih diusahakan oleh petani. Daerah yang menjadi pusat beras merah adalah KWT "Kasih Ibu" Desa Bragung Kecamatan Guluk-Guluk. kelompok wanita tani ini memproduksi beras merah yang berasal dari hasilusahatani di Desa Bragung Kecamatan Guluk-Guluk menjadi beras merah dalam bentuk kemasan. Hal tersebut merupakan salah satu bentuk kreatifitas dari anggota kelompok wanita tani "Kasih Ibu" untuk mendukung perekonomian yang lebih baik di Kecamatan Guluk-Guluk tepatnya di Desa Bragung. Selain itu, adanya sebuah produk beras merah ini secara otomatis akan menunjang ketahanan pangan nasional.

KWT "Kasih Ibu" adalah
Kelompok Wanita Tani yang sudah berdiri sejak tahun 2015 di Desa Bragung Kecamatan Guluk-Guluk. KWT ini dirintis oleh petani motivator yang bernama Ibu Kamilah El Tiha. KWT ini pada awalnya hanya menyediakan bibit padi sekaligus jasa penanaman untuk kelompok tani yang lain, baik di Kecamatan Guluk-Guluk maupun di luar Kecamatan Guluk-Guluk. Akan tetapi, pada tahun 2020 saat ini KWT "Kasih Ibu" telah menyediakan beras merah, beras hitam, dan beras putih kualitas premium dalam bentuk kemasan yang siap untuk dipasarkan. KWT "Kasih Ibu" tidak hanya dikenal oleh masyarakat Sumenep saja, namun KWT ini sudah dikenal di Jawa Timur dan tingkat nasional, di mana pada tahun 2016 KWT "Kasih Ibu" telah berhasil mendapatkan dari menteri pertanian, dan pada tahun 2017 mendapatkan penghargaan dari Presiden RI Joko Widodo pada saat acara PENAS di Aceh (Sahlan, 2020).

Masyarakat Desa Bragung Kecamatan Guluk-Guluk berupaya untuk menciptakan sebuah produk unggulan daerahnya dengan cara mengusahakan beras merah dalam kemasan di KWT "Kasih Ibu". akan tetapi tidak semua masyarakat ikut serta dalam usaha tersebut, sehingga masyarakat lainnya akan berperan sebagai konsumen beras merah. Berbicara tentang persepsi konsumen tentunya akan berbeda dan persepsi tersebut akan berkaitan langsung dengan keputusan konsumen untuk membeli suatu produk. Dengan adanya KWT "Kasih Ibu" sebagai satu-satunya usaha beras merah yang ada di Desa Bragung Kecamatan Guluk-Guluk, akan menjadi pertimbangan bagi masyarakat untuk mengonsumsi beras merah tersebut.

Keputusan pembelian seseorang dapat dikatakan sesuatu yang unik, karena persepsi terhadap objek setiap orang berbeda. Selain itu, konsumen berasal dari beberapa segmen, sehingga apa yang diinginkan dan dibutuhkan juga berbeda. Persepsi konsumen terhadap keputusan pembelian sebenarnya dipengaruhi oleh 
banyak faktor. Oleh karena itu, produsen perlu memahami perilaku konsumen terhadap produk, selanjutnya perlu dilakukan berbagai cara untuk membuat konsumen tertarik terhadap produk yang dihasilkan. Mengingat bahwasannya keputusan pembelian oleh konsumen yang berawal dari persepsi yang berbeda, biasanya konsumen akan cenderung untuk mencari informasi detail produk beras merah dan akan mengevaluasi keunggulan yang ada dalam beras merah tersebut, yang pada akhirnya akan menghasilkan sebuah keputusan pembelian. Kemudian sebagian masyarakat akan melakukan keputusan pembelian berdsarkan faktor sosial, budya, pribadi serta peran dan status dalam masyarakat.

Berdasarkan uraian di atas, akan sangat menarik jika dilakukan sebuah penelitian mengenai bagaimana persepsi konsumen terhadap keputusan pembelian beras merah dengan mengangkat judul "Persepsi Konsumen Terhadap Keputusan Pembelian Beras Merah Produksi KWT "Kasih Ibu" di Kecamatan Guluk-Guluk Kabupaten Sumenep"

\section{METODE PENELITIAN}

\section{Penentuan Lokasi Penelitian}

Penentuan daerah penelitian dilakukan secara sengaja (purposive sampling) (Burhan, 2011). Penelitian ini dilaksanakan di Kabupaten Sumenep dengan pertimbangan Kabupaten Sumenep merupakan salah satu daerah yang memiliki keanekaragaman tanaman pangan. Lokasi penelitian ditetapkan dan dilaksanakan secara sengaja pada dua pasar tradisional di Kabupaten Sumenep yaitu Pasar Anom dan Pasar Bangselok. Lokasi tersebut diambil dengan alasan merupaka tempat pemasaran beras merah produksi KWT Kasih Ibu Desa Bragung Kecamatan Guluk-Guluk.

\section{Metode Pengambilan Sampel}

Pengambilan sample menggunakan metode accidental sampling yaitu tehnik pengambilan sample secara kebetulan yang dianggap memenuhi kriteria penelitian

Responden dalam penelitian ini adalah masyarakat atau konsumen yang membeli ataupun yang tidak membeli tetapi tau tentang beras merah produksi KWT "Kasih Ibu" Desa Bragung Kecamatan Guluk-Guluk

\section{Metode Pengumpulan Data}

Data yang dikumpulkan dan diperoleh dalam penelitian ini dibedakan menjadi dua yaitu : Data primer, data sekunder.

\subsection{Metode Analisis Data}

Untuk menjawab rumusan masalah yang pertama tersebut data yang diperoleh dalam penelitian ini dikumpulkan dan kemudian dianalisis dengan menggunakan analisis deskriptif.Penjabaran analisis ini menggunakan Skala Likert.

Rumus untuk mencari persepsi masyarakat yaitu menggunakan persamaan sebagai berikut :

\section{$\mathbf{x} 100 \%$}

$$
\text { Persepsi Masyarakat }=\frac{\text { jumlah skor hasil pengumpulan data }}{\text { jumlah skor ideal tertinggi }}
$$

Untuk mengetahui jumlah skor

Jumlah Skor Seluruh Kriterium

$$
=\text { capaian jumlah skor } x \text { jumlah responden } x \text { jumlah pertanyaan }
$$

Keterangan Kriteria Interpretasi Skor :

Angka $0 \%-20 \%=$ Sangat tidak setuju / sangat tidak mengerti

Angka $21 \%-40 \%=$ Tidak setuju / tidak mengerti

Angka $41 \%-60 \%=$ Netral $/$ ragu-ragu Angka $61 \%-80 \%=$ Setuju $/$ mengerti ideal tertinggi dapat digunakan persamaan sebagai berikut :

Angka $81 \%-100 \%=$ Sangat setuju / sangat mengerti

\section{HASIL PENELITIAN}

Hasil penelitian menunjukkan bahwa secara simultan variabel rasa, harga, ketersediaan produk dan manfaat kesehatan berpengaruh signifikan terhadap keputusan pembelianberas merah produksi 
"Kasih Ibu". Keputusan untuk membeli dapat mengarah pada bagaimana proses dalam pengambilan keputusan tersebut itu dilakukan. Keputusan pembelian konsumen dipengaruhi oleh perilaku konsumen. Besarnya pengaruh keempat variabel tersebut terhadap keputusan pembelian adalah 99,7\%. Jadi, dengan melihat besarnya pengaruh keempat variabel independen tersebut terhadap keputusan pembelian maka sudah sepatutnya keempat variabel tersebut menjadi perhatian khusus bagi pihak pengelola beras merah produksi "Kasih Ibu" dalam penjualan produknya.

Pengaruh Rasa terhadap Keputusan Pembelian Beras Merah Produksi KWT "Kasih Ibu"

Hasil penelitian ini menunjukkan adanya pengaruh rasa secara parsial positif dan signifikan terhadap keputusan pembelian produk.Rasa memiliki pengaruh yang besar terhadap konsumen untuk membeli, dimana setiap konsumen dalam melakukan keputusan pembelian mengedepankan rasanya yang khas dan enak. Faktor rasa produk selalu menjadi faktor penting dalam proses dalam konteks setiap pembelian pelanggan/konsumen.

Berdasarkan hasil uji $\mathrm{t}$ diperoleh keterangan bahwa variabel rasa berpengaruh positif terhadap keputusan pembelian secara signifikan.Ini berarti semakin baik rasa yang ditawarkan berakibat pada semakin baiknyakeputusan pembelian. Besarnya pengaruh variabel rasa terhadap keputusan pembelian adalah $21,09 \%$.

Konsumen selalu memeriksa informasi rasasebelum melakukan pembelian.Rasa yang tidak khas dan kurang enak akan kurang diminati konsumen.Jadi pihak produsen harus pandai dalam memberikan rasa suatu produk.

Pengaruh Harga terhadap Keputusan Pembelian Beras Merah Produksi KWT "Kasih Ibu"
Hasil penelitian ini menunjukkan adanya pengaruh harga secara parsial positif dan signifikan terhadap keputusan pembelian produk. Harga memiliki pengaruh yang besar terhadap konsumen untuk membeli, dimana setiap konsumen dalam melakukan keputusan pembelian mengukur dengan kemampuan beli mereka. Faktor harga produk selalu menjadi faktor penting dalam proses dalam konteks setiap pembelian pelanggan/konsumen.

Berdasarkan hasil uji $\mathrm{t}$ diperoleh keterangan bahwa variabel harga berpengaruh positif terhadap keputusan pembelian secara signifikan.Ini berarti semakin baik harga yang ditawarkan berakibat pada semakin baiknyakeputusan pembelian. Besarnya pengaruh variabel harga terhadap keputusan pembelian adalah $18,75 \%$.

Konsumen selalu memeriksa informasi harga sebelum rukan pembelian.Harga yang terlalu umzу tanpa diimbangi dengan kualitas yang baik maka dapat menimbulkan kekecewaan konsumen. Jadi pihak produsen harus pandai dalam menetapkan harga jual suatu produk. Harga yang ditetapkan harus sesuai dengan daya beli konsumen. Harga mewakili sebuah persepsi seseorang tentang produk tersebut. Sehingga harga bisa membuat konsumen melakukan keputusan pembelian.

Harga yang ditetapkan beras merah produksi KWT "Kasih Ibu" mengacu pada keterjangkauan harga, daya saing harga dan kesesuaian harga dengan manfaat. Ketiga indikator tersebutmemberikan pemahaman bahwa konsumen tetap berpatokan pada tinggi rendahnya harga dalam melakukan keputusan pembelian, namun disisi lain konsumen tetap melihat nilai guna suatu barang/ batik yang berkaitan erat dengan kepuasan.

Pengaruh Ketersediaan Produk
terhadap Keputusan Pembelian Beras
Merah Produksi KWT "Kasih Ibu"


Hasil penelitian ini menunjukkan adanya pengaruh ketersediaan produk secara parsial positif dan signifikan terhadap keputusan pembelian produk.Ketersediaan produk memiliki pengaruh yang besar terhadap konsumen untuk membeli, dimana setiap konsumen dalam melakukan keputusan pembelian melihat ketersediaan produknya yang selalu ada ketika dibutuhkan. Faktor ketersediaan produk selalu menjadi faktor penting dalam proses dalam konteks setiap pembelian pelanggan/konsumen.

Berdasarkan hasil uji $\mathrm{t}$ diperoleh keterangan bahwa variabel ketersediaan produk berpengaruh positif terhadap keputusan pembelian secara signifikan.Ini berarti semakin banyak ketersediaan produk yang ditawarkan berakibat pada semakin baiknyakeputusan pembelian. Besarnya pengaruh variabel ketersediaan produkterhadap keputusan pembelian adalah $17,89 \%$.

\section{Pengaruh Manfaat Kesehatan terhadap Keputusan Pembelian Beras Merah Produksi KWT "Kasih Ibu"}

Hasil penelitian ini menunjukkan adanya pengaruh manfaat kesehatan secara parsial positif dan signifikan terhadap keputusan pembelian produk.Manfaat kesehatan memiliki pengaruh yang besar terhadap konsumen untuk membeli, dimana setiap konsumen dalam melakukan keputusan pembelian kebanyakan mengedepankan manfaatnya terhadap kesehatan yang sangat besar. Faktor manfaat kesehatan selalu menjadi faktor penting dalam proses dalam konteks setiap pembelian pelanggan/konsumen.

Berdasarkan hasil uji $t$ diperoleh keterangan bahwa variabel manfaat kesehatan berpengaruh positif terhadap keputusan pembelian secara signifikan.Ini berarti semakin banyak manfaat kesehatan dari suatu produk yang ditawarkan berakibat pada semakin baiknyakeputusan pembelian. Besarnya pengaruh variabel rasa terhadap keputusan pembelian adalah
$18,92 \%$.

Konsumen selalu memeriksa informasi manfaat kesehatansebelum melakukan pembelian.Manfaat kesehatan dari produk yang sangat sedikit akan berpengaruh terhadap keputusan pembelian konsumen. Jadi pihak produsen harus pandai menciptakan produk yang kaya akan manfaat kesehatan.

\section{KESIMPULAN}

Hasil penelitian ini menunjukkan adanya pengaruh rasa secara parsial positif dan signifikan terhadap keputusan pembelian produk.Rasa memiliki pengaruh yang besar terhadap konsumen untuk membeli, dimana setiap konsumen dalam melakukan keputusan pembelian mengedepankan rasanya yang khas dan enak. Faktor rasa produk selalu menjadi faktor penting dalam proses dalam konteks setiap pembelian pelanggan/konsumen.

Berdasarkan hasil uji $t$ diperoleh keterangan bahwa variabel rasa berpengaruh positif terhadap keputusan pembelian secara signifikan.Ini berarti semakin baik rasa yang ditawarkan berakibat pada semakin baiknyakeputusan pembelian. Besarnya pengaruh variabel rasa terhadap keputusan pembelian adalah $21,09 \%$.

Konsumen selalu memeriksa informasi rasasebelum melakukan pembelian.Rasa yang tidak khas dan kurang enak akan kurang diminati konsumen.Jadi pihak produsen harus pandai dalam memberika suatu produk.

\section{DAFTAR PUSTAKA}

Arief Rahendy dan Djawonto (2014).Pengaruh Ekuitas Merek Terhadap Keputusan Pembelian Handphone Samsung Android. Jurnal Teknologi, 25 (3)

Bungin, Burhan. (2011). Metodologi Penelitian Kuantitatif. Jakarta: Kencana Prenada Media 
Djaali. 2008. Skala Likert. Jakarta: Pustaka Utama

Faizah, dkk.2016. Persepsi Masyarakat Tradisional Pulau Mandangin Kabupaten Sampang Terhadap Tanaman Mimba. Jurnal Ilmiah Biosaintropis (Bioscience-Tropic), Volume 2 No. 1 Agustus 2016.

Hurriyati, Ratih, 2005, Bauran Pemasaran dan Loyalitas Konsumen, cetakan pertama, Penerbit : Alfabeta Bandung.

I Gede Teguh Esa Widhiarta dan I Made Wardana (2015). Pengaruh Ekuitas Merek Terhadap Keputusan Pembelian I Phone di Denpasar. Jurnal Teknologi, 30 (1)

Indrasari, Siti Dewi dan Made Oka Adnyana. (2007a). Persepsi Produsen Terhadap Beras Merah AEK Sibundong Dalam Menciptakan Peluang Pasar. Apresiasi Hasil Penelitian Padi. (2007b). Preferensi

Konsumen Terhadap Beras Merah Sebagai Pangan Fungsional. Penelitian Pertanian Tanaman Pangan.

Kristamtini dan Heni Purwaningsih. (2009). Potensi Pengembangan Beras Merah Sebagai Plasma Nutfah Yogyakarta. Jurnal Litbang Pertanian, 28 (3).

Machfoedz, Mahmud, 2005, Pengantar Pemasaran Modern, cetakan pertama, Penerbit : UPP AMP YKPN, Yogyakarta

Oktaviani, Fitri. 2015. Persepsi Masyarakat Terhadap Peran Dan Kepentingan Tokoh Dalam Penyebaran Pengetahuan Tanaman Obat. Bogor: IPB.

Prananingrum. 2007. Etnobotani Tumbuhan Obat Tradisional di Kabupaten Malang Bagian Timur. Malang: UIN Malang
Sahlan, 2020. Program GLIP Sukses Berdayakan Poktan dan Kelompok Wanita Tani Beras Merah. Bangsa Online.Com. Diakses 21 Maret 2020.

Salusu, I, 2003, Pengambilan Keputusan Stratejik untuk Organisasi Publik dan Organisasi Nonprofit, penerbit : PT. Grasindo,Jakarta

Shaharudin, et al. 2010. The Relationship between Extrinsic Atributes of Product Quality with Brand Loyalty on Malaysia National Brand Scooter.Malaysia: McGraw Hill Inc.

Simamora, Bilson, 2001, Memenangkan Pasar dengan Pemasaran Efektif dan Profitabel, Penerbit : Gramedia Pustaka Utama,Jakarta

Siti Hamidah dan Desi Anita (2013).Analisis Persepsi Citra, Desain, Fitur dan Pengaruhnya Terhadap Keputusan Pembelian Produk Handphone Samsung Berbasis Android. Jurnal Ekonomi, 29 (2)

Suardi, Didi. (2005). Potensi Beras Merah untuk Peningkatan Mutu Pangan. Jurnal Litbang Pertanian, 24 (3).

Sundjoto dan Agus sofan Hadi (2012).Pengaruh Citra Merek dan Kesadaran Merek Terhadap Ekuitas Merek Susu Cair Dalam Kemasan "Frisian Flag". Jurnal Teknologi, $40(1)$

Stevanus G.K. 2016.Persepsi Masyarakat Terhadap Tanaman Hidroponik di Desa Lotta Kecamatan Pineleng Kabupaten Minahasa.Jurnal AgriSosioEkonomi Unsrat, Volume 12 No. 2A Juli 2016.

Tjiptono, Fandy, 2006, Pemasaran Jasa, edisi pertama, cetakan kedua, penerbit : Bayumedia Publishing, Malang 
